てこの式は基準標点を任意の伸張状態にとっても， 文

3）以上 2 様の結果は, カーボン量㧍よびくり返し伸

1) Journal of App. Physs., Vol., 10, March (1939).

張によっても変らない。

2) Trans. Inst. Rubber Ind., 33, No. 1, (1957).

\title{
POISSON'S RATIO OF THE VULCANIZED NATURAL RUBBER IN THE STRETCHING
}

\section{H. Sekiguchi (Himeji Institute of Technology) \\ M. Kakiuchi (Akashi Technical College) \\ T. Morimoto (Ösaka University) \\ K. Fujimoto, N. Yoshimura (Bridge-stone Tire K.K.)}

For the vulcanized natural rubber stretched to a rupture, the change of Poisson's ratio is investigated by measuring the surface strain in longitudinal and lateral directions.

The results are summarized as follows:

(1) It is correct to take the Poisson's ratio as 0.5 when the deformation is infinitesimal at an instant of stretching. But if the deformation reaches some finite value the Poisson's ratio is decreased from 0.5 with an increasing deformation value. The former Poisson's ratio is named here the instantaneous Poisson's ratio and the latter the apparent Poisson's ratio.

(2) Both Poisson's ratios mentioned above don't vary with the same extension even when the carbonblack contents are varied and the extension is repeated.

(3) Apparent Poisson's ratio is measured on the assumption of arbitrary extension.

In an experimental expression the apparent Poisson's ratio is estimated as a function of the elongation ratio.

訂 正 本誌第40巻第 7 号, 第 8 号に下記のと打り誤りがありました。掠詑びして訂正致します。

\begin{tabular}{|c|c|c|c|}
\hline 頁 & 段 行 & 誤 & 正 \\
\hline 567 & 式（3） & $\nu=\tau_{R 2}-\tau_{R 1} /\left(R_{2} / L_{2}\right) \tau_{R 1}-\left(R_{1} / L_{1}\right) \tau_{R 2}$ & $\nu=\left(\tau_{R 2}-\tau_{R 1}\right) /\left[\left(R_{2} / L_{2}\right) \tau_{R 1}-\left(R_{1} / L_{1}\right) \tau_{R 2}\right]$ \\
\hline 583 & 存 $\uparrow 11$ & のちに記すが....... & 不 要 \\
\hline 584 & 英 110 & intachaoticddis order & into chaotic disorder \\
\hline 586 & 左 18 & 39年の 8 月 & 41 年 8 月 \\
\hline 631 & $\begin{array}{l}\text { 表中最右 } \\
\mathrm{E} \text { 項 } 14\end{array}$ & 43.2 & 432 \\
\hline \multicolumn{2}{|c|}{ 菼文題目（正） } & & $\begin{array}{l}\text { Studies on the electro-coulombmetry me- } \\
\text { thod for determination of ozone concentra- } \\
\text { tions } \\
\text { Part } 3 \text {, Ozone deterioration of rubber val- } \\
\text { canizates. }\end{array}$ \\
\hline 661 , & 62 & 661ページと662ページ本文を入換て下 & \\
\hline 会告 & 54 左 11 & 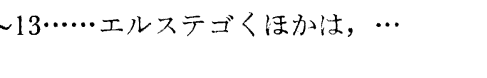 & 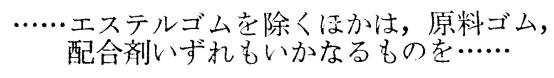 \\
\hline
\end{tabular}

